Universal Decimal Classification (UDC) 614.715613 .633

\title{
DETERMINATION OF MICRO AND NANOPARTICLES IN THE WORKPLACE AREA AT THE ENTERPRISES OF MINING INDUSTRY
}

\author{
T.S. Ulanova ${ }^{1,2}$, O.V. Gileva ${ }^{1}$, M.V. Volkova ${ }^{1,2}$ \\ ${ }^{1}$ FBSI "Federal Scientific Center for Medical and Preventive Health Risk Management Technologies", Russian \\ Federation, Perm, 82 Monastyrskaya St., 614045 \\ ${ }^{2}$ FSBEI HPE “Perm State National Research Polytechnic University”, Russian Federation, Perm, 29 Komsomolsky \\ Pr., 614990 \\ ${ }^{3}$ SBEI HPE "Perm State Medical University named after academician E.A. Wagner of Ministry of Health of the \\ Russian Federation, Russian Federation, Perm, 26 Petropavlovskaya St., 614990
}

The results of the studies of working area air in mining operations on the content of micro and nanoparticles are presented. In eight of the nine workplaces the excess is detected to the control of fine dust fraction PM10 content from 4 to 13 times, fractions RM4,0 and PM2,5 from 4 to 9 times, fraction RM1,0 from 3.5 to 9.5 times, wherein the fine fraction $R M 1,0$ is from 53 to $85 \%$. During the workplace study a significant excess of nanoparticles is found directly during the production process in relation to the control from 5 to 68 times.

Keywords: working area air, mining production, fine particles, nanoparticles.

The World Health Organization place suspended particles, especially small ones, amongst the biggest pollutants in terms of health effects.

The danger of dust particles for health is confirmed by many years of Russian and foreign studies. The greatest threat are the particles of $\mathrm{PM}_{2,5}$ and $\mathrm{PM}_{10}$ fractions. $\mathrm{PM}_{2,5}$ represents a particle with aerodynamic diameter less or equal to 2.5 micrometers in diameter and smaller, and $\mathrm{PM}_{10}$ represents particles with aerodynamic diameter smaller than 10 micrometers. $\mathbf{P M}_{10}$ and $\mathbf{P M}_{2,5}$ contain respirable particles which have such a small diameter that they can penetrate the thoracic cavity of the respiratory system. The health effects of respirable fine particles are fully documented [1, $3]$.

They are caused by short-term (several hours or days) and long-term (several months or years) exposure and include respiratory and cardiovascular disease, such as asthma and respiratory symptoms, and increased number of hospitalizations; deaths from cardiovascular and respiratory diseases, lung cancer.

There's growing scientific interest to determination of nanoparticles with aerodynamic diameter smaller than 0.1 micrometers. The substance in a nanosized state takes on new chemical, physical, and biological features not usual for macro-volume state $[2,8,10]$.

Analysis of a large number of scientific studies has shown that nanoparticles have higher toxicity than conventional microparticles, can penetrate intact through cellular barriers, as well as the blood-brain barrier into the central nervous system, circulate and accumulate in organs and tissues, cuase more severe pathologic lesions internal organs; nanoparticles are difficult to excrete because of long half-life $[5,7,11,13]$.

Toxic features of fine and ultrafine particles determine the need to control their levels in the outdoor air and workplace air at the industrial enterprises which produce suspended particles during operating activities.

Many industries - metallurgy, mining, building materials, mineral fertilizer - use mainly bulk and granular materials. During their processing and transportation, aerodispersed systems are created [6, 12]. In Russia, it is difficult to make a consistent assessment of the workplace

(c) Ulanova T.S., Gileva O.V., Volkova M.V., 2015

Tatyana Sergeevna Ulanova - Doctor of Biological Sciences, head of the Department of chemical and analytical research methods; Professor at the Department of Environmental Protection (e-mail: ulanova@fcrisk.ru; tel.: +7 (342) 233-10-37).

Olga Vladimirovna Gileva - Candidate of Biological Sciences, leading chemist of the Laboratory of elemental analysis methods (e-mail: lelyum1986@yandex.ru; tel.: +7 (342) 233-10-37).

Marina Valeryevna Volkova - chemist of the Department of chemical and analytical research methods; magister at the Department of Environmental Protection (e-mail: mari_703@ mail.ru; tel.: +7 (342) 233-10-37). 
exposure to fine dust and nanoparticles due to the lack of recent data about the particle size distribution of dust during the production processes, lack of pertinent regulatory documents on the levels of nanoparticles in the workplace air $[2,9]$.

Control of the total dust content is required in foundries, welding shops, mines, construction, cement and brick factories, etc. Industrial aerosols differ from natural ones by a higher concentration, dispersion, particle microstructure, and chemical composition.

Depending on the industry, the chemical and physical composition of dust changes which calls for systematic monitoring including studies of the disperse composition of dust, especially the finest fractions.

Due to a high level and toxicity of fine particles, it is necessary to monitor their content in the workplace air of industrial enterprises.

The purpose of the research. To study the content of micro- and nanoparticles in the workplace air at a mining enterprise.

Materials and methods. The content of fine particles in the workplace air was determined with the help of DustTrak 8533 aerosol monitor (USA). The monitor uses laser nephelometry to make measurements in a wider range of concentrations.

The range of sizes of registered particles is 0.1-15 micron. The range of measurement of aerosol mass concentrations is $0,1-150 \mathrm{mg} / \mathrm{m}^{3}$. The monitor is used to measure mass concentrations of aerosol particles in the workplace air, technical control over the AC system, air duct system, and the air quality at various facilities.

Identification of nanoparticles by size and estimation of the nanodust count were performed by means of a diffusive overspray spectrometer DAS 2702. The machine can distribute the particles by size in the range $3-200 \mathrm{~nm}$; the limit of measurement - 50000 particles per $\mathrm{cm}^{3}$.

Instrumental studies of the workplace air quality were carried out at the mining enterprise in 2015. The studies were conducted at the workstation of a mill machinist, belt filtration specialist, centrifuge operator, dosing operator in the shop with a bath for amine residues from the barrels, in drying and granulating unit (DGU), conveyor transport operator, dye preparation tank operator, operators of Venturi scrubber dryer for wet gas cleaning, granulating double-roll crusher operator, and granulating chain conveyor operator. For the purposes of a comparative analysis, we tested the air quality in the administrative building isolated from the production facility.

The enterprise under study is one of the largest potassium producers in the world responsible for 20 percent of the world's potash fertilizer output. It is the world's top producer of potash chloride. The main production department employs 11,300 workers. As for hazardous workplace factors, they include sylvinite dust (leading factor), noise, severity of the labor process, work in underground conditions.

According to scientific literature, potash dust should be classified as a mixed-type aerosol with predominance of systemic toxicity. The extent and nature of changes in morbidity, respiratory function, lipid peroxidation and activity of serum enzymes in miners reflect the intensity and duration of exposure to the dust factor [4, 9, 14].

Results and discussion. Based on the assessment of the workplace air quality at Uralkalii during the production process, we were able to determine the mass concentration of suspended particles of $\mathrm{PM}_{1}, \mathrm{PM}_{2,5}, \mathrm{PM}_{10}$ fractions (Table 1).

The highest level of dust was registered at the workplace of a drying and $4^{\text {th }}$ class granulating unit operator (double-roll crush), $5^{\text {th }}$ class dryer operator at the DGU (dye preparation tank), transport operator (conveyor) at the DGU, and $5^{\text {th }}$ class dryer operator at the DGU (Venturi scrubbers), mass concentration of suspended particles $\mathrm{PM}_{10}$ fractions (by mean value) totaled $2,197 \mathrm{mg} / \mathrm{m}^{3}, 1,520 \mathrm{mg} / \mathrm{m}^{3}, 1,500 \mathrm{mg} / \mathrm{m}^{3}, 1,487$ $\mathrm{mg} / \mathrm{m}^{3}$ respectively, by maximum value 3,467 $\mathrm{mg} / \mathrm{m}^{3}, 4,013 \mathrm{mg} / \mathrm{m}^{3}, 2,127 \mathrm{mg} / \mathrm{m}^{3}, 2,123 \mathrm{mg} / \mathrm{m}^{3}$, respectively.

The lowest level of fine dust was registered at the workplace of a dosing operator (a bath for amine residues from the barrels) at average 0,061 $\mathrm{mg} / \mathrm{m}^{3}$, which can be explained by a high level of humidity, higher than $85 \%$, and fast setting-out of particles.

A comparative analysis of the data in Table 1 has shown that 8 out of 9 studied work stations have a higher level of $\mathrm{PM}_{10}$ fine dust particles, by 4-13 times, $\mathrm{PM}_{4,0}$ fraction and $\mathrm{PM}_{2,5}$ from 4-9 times, $\mathrm{PM}_{1,0}$ fractions fromt 3,5 to 9,5 times.

Additionally, when analyzing the content of fine particles $\left(\mathrm{PM}_{1,0}, \mathrm{PM}_{2,5}, \mathrm{PM}_{10}\right)$ in the workplace air of all the facilities under study (administration, work stations), we determined that the particles sized 1 micron and smaller prevail $\left(\mathrm{PM}_{1,0}\right)$. Fine $\mathrm{PM}_{1,0}$ fraction constitutes $53-85 \%$. 
Concentration of fine dusts in the workplace air

\begin{tabular}{|c|c|c|c|c|c|c|}
\hline \multirow[t]{2}{*}{ Work station } & \multicolumn{2}{|c|}{$\mathrm{PM} 1, \mathrm{mg} / \mathrm{m}^{3}$} & \multicolumn{2}{|c|}{$\mathrm{PM} 2.5, \mathrm{mg} / \mathrm{m}^{3}$} & \multicolumn{2}{|c|}{ PM10, $\mathrm{mg} / \mathrm{m}^{3}$} \\
\hline & $\mathrm{M} \pm \mathrm{m}$ & $\begin{array}{l}\min \\
\max \end{array}$ & $\mathrm{M} \pm \mathrm{m}$ & $\begin{array}{l}\min \\
\max \end{array}$ & $\mathrm{M} \pm \mathrm{m}$ & $\begin{array}{l}\min \\
\max \end{array}$ \\
\hline Administration & $0,122 \pm 0,022$ & $\begin{array}{l}0,097 \\
0,227\end{array}$ & $0,130 \pm 0,026$ & $\begin{array}{l}0,111 \\
0,237\end{array}$ & $0,166 \pm 0,033$ & $\begin{array}{l}0,117 \\
0,308 \\
\end{array}$ \\
\hline Mill machinist & $0,577 \pm 0,115$ & $\begin{array}{l}0,316 \\
0,876\end{array}$ & $0,599 \pm 0,120$ & $\begin{array}{l}0,346 \\
0,901\end{array}$ & $0,679 \pm 0,136$ & $\begin{array}{l}0,396 \\
1,012\end{array}$ \\
\hline $\begin{array}{l}\text { Belt filtration specialist, } \\
\text { transshipping of the ready- } \\
\text { made product }\end{array}$ & $0,483 \pm 0,097$ & $\begin{array}{l}0,317 \\
0,751\end{array}$ & $0,531 \pm 0,106$ & $\begin{array}{l}0,389 \\
0,816\end{array}$ & $0,778 \pm 0,156$ & $\begin{array}{l}0,476 \\
1,420\end{array}$ \\
\hline Centrifuge operator & $0,443 \pm 0,089$ & $\begin{array}{l}0,321 \\
0,816\end{array}$ & $0,489 \pm 0,098$ & $\begin{array}{l}0,395 \\
0,873\end{array}$ & $0,769 \pm 0,154$ & $\begin{array}{l}0,475 \\
1,630\end{array}$ \\
\hline $\begin{array}{l}\text { Dosing operator in the } \\
\text { shop with a bath for amine } \\
\text { residues from the barrels }\end{array}$ & $0,061 \pm 0,012$ & $\begin{array}{l}0,041 \\
0,106\end{array}$ & $0,064 \pm 0,013$ & $\begin{array}{l}0,043 \\
0,112\end{array}$ & $0,073 \pm 0,015$ & $\begin{array}{l}0,045 \\
0,141\end{array}$ \\
\hline $\begin{array}{l}\text { Transport operator (shift- } \\
\text { based), conveyor's DGU }\end{array}$ & $0,840 \pm 0,168$ & $\begin{array}{l}0,707 \\
1,078\end{array}$ & $0,911 \pm 0,182$ & $\begin{array}{l}0,856 \\
1,150\end{array}$ & 1,500 & $\begin{array}{l}1,153 \\
2,123\end{array}$ \\
\hline $\begin{array}{l}\text { Drying and granulating } \\
\text { unit operators, operators } \\
\text { of Venturi scrubber } \\
\text { dryer for wet gas } \\
\text { cleaning }\end{array}$ & $0,947 \pm 0,189$ & $\begin{array}{l}0,730 \\
1,237\end{array}$ & $1,057 \pm 0,211$ & $\begin{array}{l}0,814 \\
1,357\end{array}$ & $1,487 \pm 0,297$ & $\begin{array}{l}1,006 \\
2,127\end{array}$ \\
\hline $\begin{array}{c}\text { Drying unit operator, } \\
\text { dye preparation tank } \\
\text { operator }\end{array}$ & $0,915 \pm 0,183$ & $\begin{array}{l}0,717 \\
2,973\end{array}$ & $1,053 \pm 0,211$ & $\begin{array}{l}0,827 \\
3,140\end{array}$ & $1,520 \pm 0,304$ & $\begin{array}{l}1,097 \\
4,013\end{array}$ \\
\hline $\begin{array}{l}\text { Granulating unit } \\
\text { operator, double-roll } \\
\text { crush operator }\end{array}$ & $1,177 \pm 0,235$ & $\begin{array}{l}0,665 \\
1,893\end{array}$ & $1,260 \pm 0,252$ & $\begin{array}{l}0,739 \\
1,997\end{array}$ & $2,197 \pm 0,439$ & $\begin{array}{l}1,220 \\
3,467\end{array}$ \\
\hline $\begin{array}{l}\text { Granulating unit } \\
\text { operator (scrubber } \\
\text { conveyor) }\end{array}$ & $0,700 \pm 0,140$ & $\begin{array}{l}0,317 \\
1,117\end{array}$ & $0,786 \pm 0,157$ & $\begin{array}{l}0,359 \\
1,220\end{array}$ & $1,323 \pm 0,265$ & $\begin{array}{l}0,648 \\
2,227\end{array}$ \\
\hline
\end{tabular}

Table 2

Analysis of the workplace air in the nanorange

\begin{tabular}{|c|c|c|}
\hline Work station & $\begin{array}{l}\text { Maximum concentration of } \\
\text { the particles, } \mathrm{mln} / \mathrm{m}^{3}\end{array}$ & $\begin{array}{l}\text { Range of the particle size with } \\
\text { the maximum concentration, } \mathrm{nm}\end{array}$ \\
\hline Administration & $1012 \pm 202$ & $30-35$ \\
\hline Mill operator & $13805 \pm 2761$ & $20-25$ \\
\hline $\begin{array}{l}\text { Filter operator (shift-based), belt conveyor for transferring } \\
\text { ready-made products }\end{array}$ & $6075 \pm 1215$ & $10-15$ \\
\hline Class 3 centrifuge operator, centrifuges & $9698 \pm 1940$ & $10-15$ \\
\hline $\begin{array}{l}\text { Class } 4 \text { dosing operator, bath for amine residues from the } \\
\text { barrels }\end{array}$ & $42468 \pm 8494$ & $15-20$ \\
\hline Transport operator (shift-based) DGU (containers) & $54279 \pm 10856$ & $25-30$ \\
\hline $\begin{array}{c}\text { Class } 5 \text { drying and granulating unit operators, operators of } \\
\text { Venturi scrubber dryer for wet gas cleaning }\end{array}$ & $68466 \pm 13693$ & $45-50$ \\
\hline class 5 drying unit operator, dye preparation tank operator & $67144 \pm 13429$ & $45-50$ \\
\hline $\begin{array}{c}\text { class } 4 \text { granulating unit operator, double-roll crush } \\
\text { operator }\end{array}$ & $19440 \pm 3888$ & $35-40$ \\
\hline Class 3 granulating unit operator (scrubber conveyor) & $26218 \pm 5243$ & $25-30$ \\
\hline
\end{tabular}




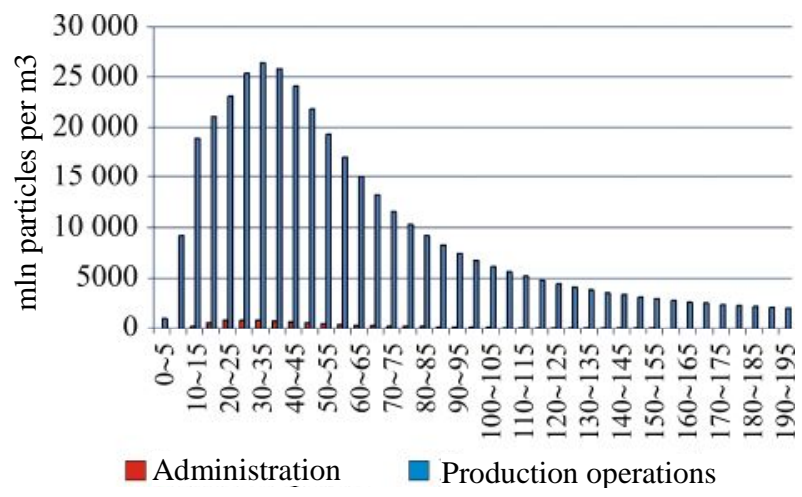

Fig. 1 A comparison of the nanoparticle concentrations during the production operations and in the administrative building

Elevated levels of fine $\mathrm{PM}_{1,0}$ fraction particles implies the presence of even finer particles and invites further studies. The research results are presented in Table 2 and in figures below.

In the air of the administrative building (comparison work station), the maximum concentration of the particles is within the $25 \mathrm{~nm}$ range, number concentration 953-1012 million particles per $\mathrm{m}^{3}$ (with the maximum of particles in the range $\sim 30-35 \mathrm{~nm}$ ).

The maximum number concentration of nanoparticles was registered in the air at the work station of class 5 DGU dryer operator (dye preparation tank), 5 class DGU dryer operator (Venturi scrubbers for wet gas cleaning) and totaled $\sim 63925-68466 \mathrm{mln}$ particles per $\mathrm{m}^{3}$, with the maximum particles sized $40-50 \mathrm{~nm}$.
In general, we established an overall excess in the concentration of nanoparticles in the workplace air during the production operations as compared to the control from 5 to 68 times.

The study of the air quality at the dosing operator's work station (a bath for amine residues from the barrels) had interesting results: the concentration of suspended particles was at a minimum, 2 times lower than in the administrative building; PM1,0 fraction here totaled approximately $83 \%$.

A fractional analysis of the nano-sized particles for this process showed a rather high value of the number concentration exceeding the control by more than 40 times, 41822 - $42468 \mathrm{mln}$ particles per $\mathrm{m}^{3}$ with the maximum of the particles sized 10-20 нм.

Conclusion. This study can be used as reference material when assessing labor conditions, hazardous factors, and professional risk in the production process and use of the materials that contain micro- and nanosized particles as wells as operating processes that produce those.

Moreover, the results of the study above raise the question of monitoring the levels of suspended particles in the workplace air. The obtained results confirm the need for the assessment of the fractional composition of the workplace air for further development and validation of the standards for maximum permissible concentrations which is significant from the hygienic point of view in the assessment of employee health, prevention and treatment of occupational diseases.

\section{References}

1. Golohvast K.S. Nano- i mikrorazmernye chasticy atmosfernyh vzvesej i ih jekologicheskij jeffekt (na primere gorodov juga dal'nego vostoka): avtoref. dis. ... d-ra biol. Nauk [Nano- and micro-sized particles of atmospheric mists and environmental benefits (on the example of cities in the south of the Far East): Abstract Dis. ... Dr. of Biol. Sciences]. Vladivostok, 2014, 310 p. (in Russian).

2. Onishhenko G.G. Organizacija nadzora za oborotom nanomaterialov, predstavljajushhih potencial'nuju opasnost' dlja zdorov'ja cheloveka [Organization of supervision over the circulation of nanomaterials posing a potential danger to human health]. Gigiena i sanitarija, 2011, no. 2, pp. 4-9. (in Russian).

3. Rukovodstvo po ocenke riska dlja zdorov'ja naselenija pri vozdejstvii himicheskih veshhestv, zagrjaznjajushhih okruzhajushhuju sredu R 2.1.10.1920-04 [Guidelines for assessment of health risk when exposed to chemicals polluting the environment R 2.1.10.1920-04]. Moscow: Federal'nyj centr Gossanjepidnadzora Minzdrava Rossii, 2004. 143 p. (in Russian).

4. Strutinskij G.M. Gigiena truda pri dobyche polimernoj kalijnoj rudy: avtoreferat, dis. ... kand. med. nauk [Occupational health in polymer potash mining: Abstract Dis. ... Cand. of Medicine]. Moscow, 1990, 24 p. (in Russian).

5. Chen Z., Meng H., Xing G. et al. Acute toxicological affects of copper nanoparticles in vivo. Toxicology letters, 2006, no. 163, pp. 109-120.

6. Brimblecombe P. Air composition and chemistry. Cambridge: Cambridge Univ, press, 1996, 253 p.

7. Hoet P.M., Bruske-Hohlfeld I., Salata Nanoparticles O.V. Nanoparticles - known and unknown health risks. Journal of Nanobiotechnology, 2004, no. 2, 12 p. 
8. Oberdцrster G. Toxicokinetics and effects of fibrous and nonfibrous particles. Inhalation Toxicology, 2002, no. 12 , pp. $28-56$.

9. Cormier S.A., et al. Origin and health impacts of emissions of toxic by - products and fine particles from combustion and thermal treatment of hazardous wastes and materials. Environ Health Perspect, 2006, no. 114 (6), pp. 810 817.

10. Nemmar A., Hoylaerts M.F., Hoet P.H., Nemery B. Possible mechanisms of the cardiovascular effects of inhaled particles: systemic translocation and prothrombotic effects. Toxicology letters, 2004, vol. 149, pp. $243-253$.

11. Sahoo S.K., Parveen S., Panda J.J. The present and future of nanotechnology in human health care. Nanomedicine: Nanotechnology, Biology and Medicine, 2007, no. 3, pp. 20-31.

12. Amato F., Pandolfi M., Moreno T., Furger M., Pey J., Alastuey A., Bukowiecki N., Prevot A.S.H., Baltensperger U., Querol X. Sources and variability of inhalable road dust particles in three European cities. Atmospheric Environment, 2011, vol. 45, no. 37, pp. 6777-6787.

13. Stern S.T., McNeil S.E. Nanotechnology safety concerns revisited. Toxicology science, 2008, no. 101 (1), pp. 4-21.

14. Takenaka S., Karg E., Roth C. et al. Pulmonary and systematic distribution of inhaled ultrafine silver particles in rats. Environmental health perspectives, 2002, no. 109, pp. 547-551. 